\title{
The Role of Religion in James Joyce`s Dubliners: Cultural Materialism Reading
}

\author{
Maryam Jafari ${ }^{1, ~ *, ~ M a h n a z ~ S o q a n d i ~}{ }^{2}$, Shiva Zaheri Birgani ${ }^{3}$ \\ ${ }^{1}$ Science and Research Branch, Islamic Azad University, Tehran, Iran \\ ${ }^{2}$ English Language and Literature Department, Faculty of Humanities, Semnan University, Semnan, Iran \\ ${ }^{3}$ Department of English Language and Literature, Boroujerd Branch, Islamic Azad University, Boroujerd, Iran
}

Email address:

Marry.jafaryi@gmail.com (M. Jafari)

${ }^{*}$ Corresponding author

\section{To cite this article:}

Mojgan Gaeini Mahnaz Soqandi, Shiva Zaheri Birgani. The Role of Religion in James Joyce`s Dubliners: Cultural Materialism Reading. Advances in Sciences and Humanities. Vol. 5, No. 2, 2019, pp. 55-64. doi: 10.11648/j.ash.20190502.13

Received: March 19, 2019; Accepted: May 23, 2019; Published: June 13, 2019

\begin{abstract}
Language, Social identity and Religion are three major concerns of cultural studies. Language in literary texts plays a major role in constructing meaning and reflecting the author's intention. Likewise religion as a cultural politics is a dominant factor in shaping mind as well in affecting the framework of literary text. Religion is one of the emerging issues in the modern era and forms the backbone of most literary works. Religion as a theme is seen to influence the operation of those who believe in it. It forms the functional framework that predetermines ones actions and behavior. Furthermore, social identity decides on the status of the social class and their material life situation. Social identity relates to how we identify ourselves in relation to others according to what we have in common. All these issues are interrelated since they all cooperate and construct a social and cultural materiality. Proper cultural and social materials and issues such as religious matters. His major short story collection, Dubliners, revolves around the lifestyle of the Irish middle-class in Dublin around the late 1800s and early 1900s. This collection is decorated with violated norms and ritualistic behavior that are part of social constructs. Addressing social, religious and cultural issues, cultural This study aims to clarify how James Joyce`s Dubliners reflects the notions of language, social identity and religion as cultural practices and how they construct social and cultural products within the framework of cultural materialism to show how James Joyce criticizes Irish culture at the beginning of the Twentieth century.
\end{abstract}

Keywords: Cultural Materialism, Social Identity, Language, Religion, Infrastructure

\section{Introduction}

This paper aims to investigate how the notion of religion as a cultural practice which construct social and cultural products function in James Joyce's Dubliners within the framework of Cultural Materialism. Cultural materialists seek to draw attention to the processes being employed by contemporary power structures, such as the church, the state or the academy, to disseminate ideology. The focus of this study is on Raymond Williams's cultural materialism. What Jams Joyce wants to insist on his novels is unreliability of religion in an unreliable world. The selected stories of Dubliners that are discussed in this chapter are "The Sisters", "An Encounter", "Araby", "The Dead", "The Boarding House" and "Grace".
The messy spiritual breakdown of modern society declines the chances of spiritual stability and increases disorder of once life. Irish society suffers from spiritual sterility that conducts their life and inflicts the Dubliners 'behavior. Such conduct deprives them, making them preys of a superficial world full of delusion and seclusion. Joyce's Dubliners is a spiritually famished prisoner serving time in a barren cell to which there seems to be no key. [1].

Religion is predominated in this story. It mentioned numerously, father Flynn who was always unhappy and usually looked sad. The answer to his disappointment is recognized to the time when he unintentionally broke his chalice. He felt guilty of himself and he had to go to the church and hide himself in darkness just because he felt he had sinned against God. By breaking the chalice, Father 
Flynn showed dreadful overlook for the vessel that generally carries the holy wine, the transubstantiated blood of Christ, even though the chalice had contained nothing at the time. It is the first evidence in Dubliners that religion is a dangerous and deceptive force. Not only does the chalice cause the priest's madness, it comes back to taunt his dead body. If we put consideration, we will discover that Father Flynn, the disbelieving priest, comes to terms with his sin of breaking the chalice that he even comes to terms with his discovery of the silence of God. And even the boy, who discovers Flynn's concerned past, will be on the verge of making the same discovery, a certain religious kinship between him and the priest. It is his strong belief in religion that immediately edicts his conscience which then has a direct have an effect on his view in his view of life.

Language, Social identity and Religion are three major concerns of cultural studies. Language in literary texts plays a major role in constructing meaning and reflecting the author's intention. Likewise religion as a cultural politics is a dominant factor in shaping mind as well in affecting the framework of literary text. "Religion is one of the emerging issues in the modern era and forms the backbone of most literary works. Religion as a theme is seen to influence the operation of those who believe in it. It forms the functional framework that predetermines ones actions and behavior.

In a homeland which had for so long encompassed Catholicism, Joyce made a bold move in attacking it as he did. Both Ireland and the Catholic Church had let Joyce down, meaning that it is very well possible that Joyce could have included Ireland in his anger when he stated forcefully of the Church, "I make open war upon it by what I write and say and do" [2].

\section{Method}

Cultural Materialism as a postmodernist critical approach has root in the contextual approaches. It tries to remove the deficiencies of the traditional contextual approaches and to provide a practical and well-organized theory in literary criticism. Some critics believe that the background of Cultural Materialism refers to the Historical oriented approaches, but some others maintain that it is the result of Marxism. It is important that Cultural studies have significant role in the construction of Cultural Materialism.

Contextual approaches were constructed after traditional approaches and New Criticism. Their background goes back to the nineteenth and early twentieth centuries when scholars asked to what extent literary texts were under the influence of the historical, political, economical, philosophical, religious and psychological contexts of their productions. One example of the contextual approaches was Marxist criticism which regards the production of literary texts as "the interface of material and socio-economical circumstances" [3]. Class and economic structures were the particular focus of Marxist critics.

Williams defines Residual as "some social or cultural practice which has been formed in the past, but it is still active and effective in the present cultural system like organized religion" [3]. A residual cultural element is usually at some distance from the effective dominant culture, but it is some part of it which is embedded in cultural system. The concept of emergent for Raymond Williams means "the creation of new meaning and values, new cultural practices and new relationships within the dominant structure" [3]. It is important to distinguish between those emergent which are elements of new stage of the dominant culture and those which are actually other element or oppositional to dominant system.

Dominant has significant connotation in Cultural Materialism generally and in cultural system specially. Dominant in Williams's terminology is very near to the meaning of Hegemony in Antonio Gramsci's ideology. Hegemony refers to the domination of one people or group by another. According to Gramsci dominant class in the society "makes compromises, provides moral and intellectual leadership and creates institution and social relations in order to establish a basis for the consent of all classes and sections of society" [4].

Raymond Williams as the founder of Cultural Materialism also insists that politics for its part is always cultural. The history of the Left and the labor movement is the history of attempts to develop an alternative culture a long, complex and contradictory process. Williams asserts that the space for alternatives is never entirely blocked: "no mode of production and therefore no dominant social order and therefore no dominant culture never in reality includes or exhausts all human practice, human energy and human intention" [5]. There is always space for opposition, for thinking and action directed towards the elaboration of another social order. In Cultural Materialistic viewpoint the dominant order is not unavoidable real world. In confrontation of the dominant order, according to Williams, we face "a set of identifiable processes of real politic and force majeure, of nameable agencies of power and capital, distraction and disinformation" [6]. The main task of Cultural Materialists is to establish the lines of development for an alternative as Williams stresses: It is only in a shared belief and insistence that there are practical alternatives that the balance of forces and chances begins to alter. Once the inevitabilities are challenged, we begin gathering our resources for a journey of hope. If there are no easy answers there are still available and discoverable hard answers, and it is these that we can learn to make and share. [40, 175]

Jonathan Dollimore and Alan Sinfield, the great practitioners of Cultural Materialism, assert that the principle of reliable criticism in political agenda: Cultural Materialism does not, like much established literary criticism, attempt to mystify its perspective as the natural, obvious or right interpretation of an allegedly given textual fact. On the contrary, it registersits commitment to the transformation of a social order which exploits people on grounds of race, gender and class. [7]

Cultural Materialism in achieving its political goals adopts two methods. In some cases it begins to interpret literary 
texts from the standpoint of oppositional or dissident subculture. In other cases it takes the form of an examination of the material incidents in which conservative ideologies function. Thus, the first way relates to the dissident viewpoint, and the second method is from conservative outlook.

Dissidence in Cultural Materialistic ideology is a very crucial term. Its literal meaning is "the resistance against the dominant order without prejudging an outcome" [8], but according to Sinfield dissidence operates necessarily with reference to the dominant structures: "It has to invoke those structures to oppose them; it means that any position supposes its intrinsic op-position" [8].

The important point in understanding the meaning of dissidence is that it is not thoroughly opposed to power, and it is not also an antithesis which tries to reverse the values and strategies of power. It is instead very close to the structures of power and indeed is produced by the internal contradictions of these structures. Of course, it implies a deviation from the rules of the dominant culture, but it may be that dissidence achieves no reaction from power.

Recent British Cultural Materialist theory claims reading dissidence in literary texts. Brannigan brings under the question the claim of those critics in investigation of the essence of the dissidence: It is the idea of conflict and contradiction in Cultural Materialist reading that prepares the ground for incorporation of the dissident within the body of the dominant. The power of the dominant culture can only be seen in its containment of the threat of dissidence. In Cultural Materialism dissidence is a phenomenon occurring at specific junctures of the history of a text, which is then subsumed, hence the necessity of Cultural Materialist revitalizations of the dissident perspective. (179)

Higgins states that concisely the manifestation of Cultural Materialism is "the formation of critical practice in articulating dissident perspectives on contemporary cultural politics" (300). Such idea sometimes gives its practitioners a sense of political and social mission.

Cultural Materialism seeks the way in which subversion, dissidence, resistance and all forms of political oppositions could be represented. In this way most of the time it scrutinizes the theatre as "a prime location for the performance of the interaction between the States power and other groups of cultural system" [9]. As we see the first practical attempts of Cultural Materialistic criticism refers to the analysis of the Renaissance Drama.

Abrams argues that Cultural Materialism wants to transfer to the center of cultural study the Marginal or excluded literary works and artistic productions of women, the working class, non-white groups and Third -World culture. Its critics lead their interpretations and their discussion "toward the explicit political end of reforming the existing power-relations which, they consider, are dominated by a privileged gender, race, class or ethnic group" [254].

By Cultural Materialistic reading of Dubliners (1914), the stories were written when Irish nationalism was at its peak, and a search for a national identity and purpose was raging; at a crossroads of history and culture, Ireland was jolted by various converging ideas and influences. They center on Joyce's idea of an epiphany: a moment where a character experiences a life-changing self-understanding or illumination. Many of the characters in Dubliners later appear in minor roles in Joyce's novel Ulysses. The initial stories in the collection are narrated by child protagonists, and as the stories continue, they deal with the lives and concerns of progressively older people. This is in line with Joyce's tripartite division of the collection into childhood, adolescence and maturity.

Dubliners (1914) is certainly important in that he talks within it about his life and his entourage (ibid). It takes a form of naturalistic depiction of Irish middle class in life and around Dublin in the early 20th century. About Dubliners Attridge states that: The stories are interested in issues of identity and the self, but they are equally involved with issues of politics and what it feels like to be a part of Ireland as a nation with a particular history and a particular place within the British Empire. (90)

Prendergast in Cultural Materialism stated that Religion is one of the emerging issues in the modern era and forms the backbone of most literary works. Religion as a theme is seen to influence the operation of those who believe in it. Religion is predominated in Dubliners. It forms the functional framework that predetermines ones actions and behavior. James Joyce's Dubliner is a vivid collection that depicts conflicts that exist between the modern era and the early times of the 20th century in terms of beliefs and cultural practices (27). Joyce advances the significance of Dubliners by providing readers with insights into the current transformed world (29). According to Joyce, the current era is the type that compels people to know more about the world they live in and fully understand the potential that it possesses [10]. Foster mentions that" The writer uses life in Dublin to forward his goal by indirectly criticizing its beliefs and exposing certain failures in their fundamental beliefs hence implying that not all beliefs are good. Beliefs can change one's life either to the negative or to the positive depending on the circumstances. In the story of Dubliner, Joyce depicts Dublin to be a city where religious oppression is at optimum and intolerable to the citizens" (36).

\section{Result}

\subsection{The Role of Religion in "The Sisters"}

In the story, 'The sisters', Joyce uses Dublin as a country whose citizens have a strong belief in religion that they have become slaves to it (35).

Soon enough, though there is no exact explanation of has clearly happened to the priest and what really causes his mental disintegration, the reader knows about the priest from a second hand source and his sister Eliza tells the aunt ant the unnamed boy that everything goes bad after her brother breaks the chalice. After this incident the priest has become odd, though the broken chalice contained nothing. 
Significantly Father Flynn's hold of the chalice symbolizes his insecure grasp on spirituality and his failure as a priest and consequently he cannot offer communion and an empty chalice lies on his breast in death [11].

The emptiness of the chalice does not enable the clergyman to fulfill the rituals of the Last Supper. In this essence, the void chalice symbolizes the hollowness of Catholicism as a failed institution. Though Eliza is acquainted with the Catholic rites, she offers her guests the sherry and the crackers which symbolize bread and wine. But the unnamed boy refuses to take some and he symbolically he refuses to be part of the ceremony of communion.

The paralysis is the inability of physical movement, but it is also a spiritual, social, cultural, political, and historical malaise [12]. It does refer to the inability to function correctly and in Dublin's context, it suggests the Dubliners who are naturally paralyzed and they are living a paralyzed city. In the dead Julia Morkans expresses her indignation about the pope who has decided to turn out the women out of the choirs (123). Such decision is unfair on the behalf of females who have singing voices. In The Sisters the one can see that though Father Flynn is a priest, he fails in his religious duties and he presents the real state of Irish Church. Clearly enough, Father Flynn symbolizes the paralyzed Catholic Church and its drawbacks on the individuals, especially children. Yet the old priest teaches the boy great deal of things. The sickness of the spiritual matters affects the social norms and provides an incurable disease in society. This latter becomes helpless and disorientated from its path.

Religion is predominated in this story. It mentioned numerously, father Flynn who was always unhappy and usually looked sad. The answer to his disappointment is recognized to the time when he unintentionally broke his chalice. He felt guilty of himself and he had to go to the church and hide himself in darkness just because he felt he had sinned against God. By breaking the chalice, Father Flynn showed dreadful overlook for the vessel that generally carries the holy wine, the transubstantiated blood of Christ, even though the chalice had contained nothing at the time. It is the first evidence in Dubliners that religion is a dangerous and deceptive force. Not only does the chalice cause the priest's madness, it comes back to taunt his dead body. If we put consideration, we will discover that Father Flynn, the disbelieving priest, comes to terms with his sin of breaking the chalice that he even comes to terms with his discovery of the silence of God. And even the boy, who discovers Flynn's concerned past, will be on the verge of making the same discovery, a certain religious kinship between him and the priest. It is his strong belief in religion that immediately edicts his conscience which then has a direct have an effect on his view in his view of life.

Notwithstanding all this, in the same story, most characters seem to be deeply rooted in religion simply from the way they express themselves. The phrase 'may God have mercy upon him' has been over and over said through a variety of characters when referring to the late father Flynn. They all suppose that each and every word they utter is offensive to
God in a way. Narrator in this story appears to be extensively affected through what he hears mainly from his seniors. At some factor in the story, he had a dream that was once a result of over-meditating over positive matters that were instructed to him through Cotter. The narrator seems to be appreciably affected his emotions. This is very obvious when he goes with his aunt to the late father Flynn's home. As they pray over the useless corpse, the narrator appears afflicted and tries to think about that the corpse was once smiling at him. As Mr. Cotter discusses with the narrator's parents, he feedback in a assertion on the narrator's relationship with the priest. He says that it is not good for such a young boy to relate with an aged priest. He knew very nicely that father Flynn was a spiritual stereotype and it would be unfair if such beliefs were inculcated into the innocent mind of the younger boy. The researcher strongly believe that Mr. Cotter had viewed how a lot the narrator's sense of right and wrong had been affected. As the narrator considers over the priest's demise, he finds himself thinking about his own death. It is as if there used to be some inner pressure that used to be governing the narrator's idea because on every occasion he idea of anything, something just got here in and sort of redirected his thinking. He was once always crammed with a feeling of guilt. Having been nearer to anybody whose faith was once deeply rooted in the catholic religion, nothing else should be predicted from the narrator other than the beliefs of the late father Lynn. It is something that the narrator can't keep away from due to the fact it comes automatically. Now that the narrator had been uncovered to sturdy beliefs at a highly soft age, the effect on his mind used to be so good sized that everybody should see it from his behavior. In this story, religion is vividly brought out as a major theme and it seems to have a stronger influence on how the people of Dublin carry out their activities. Generally, the writer wants to show how people are tied up by whatever they believe in and as a result how these beliefs affect their consciousness $[36,21]$.

Regarding the debut of Joyce as a young believer could bring a perspective on the effects of Catholicism in his stories that would give the impression of a faithful representation of religion in Ireland. Reading Dubliners, the religious aspects of nearly all the stories, but focuses mainly on "The Sisters", "Eveline" and "Grace". Joyce did leave the Church as a young adult and did not return to it.

James Joyce's dissatisfaction with religion, church and priesthood in his short story The Sisters could be better understood if the relationship between the "nets" of Irish society and his view of artist in A Portrait of the Artist as a Young Man (1916) was properly comprehended (1961: 327). One of the "nets" in the Althusserian sense is religion and the Roman Catholic Church with its traditional, stagnant, restrictive and "paralytic" nature and structure, which obviously inhibits the self or the artist from what Joyce metaphorically calls "flight", a "flight" which would avail an artist of chance or opportunity to be free and creative by going beyond ordinary aspects of life shaped by the "nets" of society (327). He represents his frustration with the Catholic 
Church and priesthood and then artistically critiques the basis, image and authority of the priesthood through different ways and strategies in the story to flee from the dogmatic nature and restraining climate of the religion, he artistically stresses the view that the Catholic Church and Dublin are imbued with "the special odour of corruption which, I hope, floats over my stories' in, or they are the center of paralysis" [12].

Indeed, "the special odour of corruption" and "paralytic" nature of the town and religion doesn't inspire freedom physically and mentally in life. Religion as having "the special odour of corruption" as well as being "the center of paralysis "Joyce regards the established religion as an important obstruction, which, he thinks, does not allow the artist to create a space of his own to manoeuvre his artistic vision of "flight", vision and vocation beyond the borders of "nets" of Irish society. Their understanding of Catholicism is purposefully perverted by Joyce to expose the limited knowledge of theology among the faithful. Throughout his reading of Dubliners, Joyce was highly attentive in alternating the accuracy and inaccuracy of his characters' knowledge of their faith, and that this demonstrates Joyce's position that Catholicism in Ireland created docility and compliance in the lower class and lower-middle class. Geert Lernout in his book entitled Help My Unbelief (2010) states:

James Joyce and Religion argues that James Joyce lost his faith in the Roman Catholic Church and its dogma and that the historical conditions of Joyce's loss of his faith provide an inescapable context for reading Joyce's works. Lernout explains the beliefs and practices of the Church of Rome that Joyce encountered from the nineteenth century to the beginning of the twentieth century. By attending to the tradition of freethinking writers of the same period, he demonstrates that Joyce's revolt against Christianity was part of a larger network of anti-religious thinking in literature and philosophy. [13]

The sisters is important because it is Joyce's critic on society and religion. This is an example of how one religion is placed as the more superior religion and that is a certain way one should live their life in order to be faithful to their religion. In his first important work, Culture and Society (1958), Williams reviewed the mainly conservative English tradition of social thought. Its resonance and appeal depend on how it organized culture, conceived as ideas or ideals of perfection removed from material social life, as a critique of specific large-scale changes involving industry, democracy, class and art. In a class divided society, "culture" was opposed to business, urban massification, and possessive individualism. Religion is omni-present in Dubliners, yet the religious people who are supposed to be pious, they instead do awful things and they consequently suffer from their individual choices. The Sisters which are written in italics are the seeds of the paralytic spiritual Dublin of the twentieth century life and the power of these three words has a great spiritual effect on the Dubliners. The very sound of the world. Paralysis casts a morbid fear on the boy as he, every night as I gazed up at the window I said softly to myself the word paralysis. It had always sounded strangely in my ears, like the word gnomon in the Euclid and the word simony in the Catechism (1).

Using Joyce's allusion, the Catholic Church is good-fornothing and Father Flynn represents «the corrupt features of Irish Catholicism, turning spirituality into a burden and torture» [13]. In addition to that Paul Dubois believes that the true cause of the increase in mental disease is Roman Catholics' [13].

We see another critic on religion in the next story in Dubliners called "An Encounter". In "An Encounter" two boys, already dissatisfied with their father-dominated schoolsociety represented by Father Butler whose memory haunts them all day, seek escape, hoping to find more meaningful experiences elsewhere. Deciding that adventures "must be sought abroad" (31), they plan a truant day by the sea. Their adventure is meeting an elderly man who commandingly gives them advice on books and sex. To their abhorrence and fright he turns out to be a pervert whose psychological paralysis is imaged in his conversation which "as if magnetized... seemed to circle slowly round and round its... center" (37). This story depicts quite a gathering with a pederast; it pictures the sterility of ambition in Irish society. Raymond Williams believes that in capitalistic system everything is covering by capitalism. We see that religion paralyzed people in stories of Dubliners. Religion has a significant effect on the believers mind and even goes ahead to dictate the kind of life they live.

\subsection{The Role of Religion in "The Encounter"}

In the encounter, the theme of religion still integrates a stronger influence on the characters' personal lives. As a result of the utterer associate degreed his friend Mahony leave for associate journey, they meet associate previous man world organization agency, from the define, look intimate a touch just like the former late father Lynn world organization agency had a sturdy influence over the narrator's realization. Their voice communication instills loads of concern at intervals the young boys and makes them suspicious of the old man. The previous man appearance to impute some quite belief at intervals the young boys since at their age they seem innocent and have an inclination to believe everything they hear notably from mature people a bit like the old man. Religion has a significant influence on the believers mind. The old man in the this story seems to be living a disappointed life just like father Flynn. Father Flynn making an attempt to impart his funny ideologies in to the innocent young children. His belief that forms his religion had become half and parcel of him and influenced everything he did. He was too conservative and he influence others. In these two stories, fear is seen to take center stage in religion. This can be however father Flynn managed to influence the lifetime of the narrator. The old man within the story 'the encounter' and the old priest within the initial story 'the sisters' exploited their social position of giving smart counsel to the young children however instead capitalized on such opportunities to influence into the minds of the children. They use enticing 
words in capturing the attention of the children. In the encounter, Joe Dillon's behavior appeared at some point to be strange even as they played their childhood games. His behavior and what he believed makes him different from other children and Religion tends to possess a stronger influence on the children.

The concept of dissidence and reaction against the dominant subculture is the most significant point in Cultural Materialism. In capitalistic context the concept of dissidence is very near to the recognition of Other as the result of resistance against ruling class's norms and orders. Consequently, the destiny of Other is suppression or punishment. Most of the time this part of society becomes marginalized or excluded, because the rest of society during ideological hegemony has lost its concerns towards them, and look at them as the outsiders or enemies: The capitalist lacks an ideological state apparatus ensuring the eventful reproduction of an exploitative mode of production for the ruling class. Yet, in political commitment to, and identification with, 'the other' -an identification that takes the form of an avowal of critical partiality- lies the danger that cultural materialistic critic will not fail to attempt to fill out the lack, the partiality, that 'the other' occupies in his or her desire for the desire of the institutional Other. (15)

Education and religion are as hegemonic discourses in the society. Antonio Gramsci argues that "The ideological superstructure (religion, morality, law, art) was seen as little more than a reflection of underlying economic realities. Societal change was determined not by thought or action but by impersonal historical, political, economic processes that had very little to do with human will or initiative" (20) This way, a culture of reconciliation was developed and the proletariat acquired the illusion that their own good was not distinguishable from that of the bourgeois.

At school, they were solely allowed to read the roman history associate degreed it absolutely was an offense reading different materials particularly from the west. It's owing to what the priests believed in this created them regard different literature aside from the roman history as useless and industrial. Leo Dillon receives a stern warning once it's discovered that he was having small book on the West of that father Butler refers to as being rubbish. The narrator conjointly states that the open rebuke by father Butler stirred up some worry in him however every now and then once he was far from school, such feelings would still return associate degreed he would begin developing an interest in what father Butler had warned them to not read. Dillon's parents also are seen to be too spiritual and that they won't to move to church each evening for fellowship. Father Butler's words appeared to instill heaps of worry in Leo Dillon's life as a result of he even ne'er turned up for the journey as that they had planned however selected to travel to high school instead. On their journey as they walked on North strand road, two boys started throwing stones at them since they thought that the teller and his friend were Protestants. This clearly shows that this society was powerfully catholic and no different religion was allowed. it's conjointly shocking that such an early age, the two young boys were throwing stones at the narrator and his friend had already been influenced and knew that protestants weren't allowed in this community. They fought for what they believed in and will not permit anyone to change them.

\subsection{The Role of Religion in Araby}

In the story 'Araby', the narrator's aunt was too religious and this is evident when she tells the narrator that he would have to cancel his visit to the bazaar that 'night of the lord'. She mentioned everything to God meaning that she had deep faith in the catholic religion till it was openly showed without her notification. There are a number of words or phrases in "Araby" that refer to religion. The opening line refers to "Christian Brothers' School" setting the boys free and it refers to a priest who had died "in the back drawing room" (20). This is basically another placement of Joyce's dislike of hypocritical priests, and the end he saw in store for them.. The second paragraph opens with "The former tenant of our house, a priest, had died in the back drawing-room" and mentions religious books and spiritual qualities.

Obviously, the narrator over and over again thinks about and describes his crush, Mangan's sister, in religious terms. At one point he compares her to a "chalice" that he is defending from a "throng of foes," a reference that seems to compare her to the Holy Grail. At other times, he literally seems to worship her:

"Her name sprang to my lips at moments in strange prayers and praises which I myself did not understand. My eyes were often full of tears (I could not tell why) and at times a flood from my heart seemed to pour itself out into my bosom. I thought little of the future. I did not know whether I would ever speak to her or not or, if I spoke to her, how I could tell her of my confused adoration" (17).

That the narrator doesn't even understand his prayers to Mangan's sister seems to imply that he is not idolizing Mangan's sister on purpose. Instead, it seems as if his Catholic upbringing has defined the form of how he understands anything for which he feels strong emotion. There is another example that shows religion control over society in Araby:

"The former tenant of our house, a priest, had died in the back drawing room. Air, musty from having been long enclosed, hung in all the rooms, and the waste room behind the kitchen was littered with old useless papers. Among these I found a few paper-covered books, the pages of which were curled and damp.... The wild garden behind the house contained a central apple-tree and a few straggling bushes under one of which I found the late tenant's rusty bicyclepump. He had been a very charitable priest; in his will he had left all his money to institutions and the furniture of his house to his sister" (16).

At the same time, it is also possible to interpret the text as criticizing Catholicism and religion, as implying that the narrator's religious background may have set him up to be unsatisfied, because nothing can meet divine standards. Conversely, that, just as the narrator's "worship" of 
Mangan's sister is shown to be impossible because nothing can match his imaginative ideals, the story is implying that the same applies to religion in general that worshipping anything is unreasonable and bound to end in disappointment.

Williams briefly refers to Newman's idea in which for him "culture had a reality inexperience, as an element of the divine perfection" (138). He, then, directs the argument towards Laurence's idea about culture when he says, "It is with the life about us that all our concern lies; and culture's double end is simply this to make us appreciate that life, and to make that life worth appreciating" and that, "the aim of culture is to make us better company as men and women of the world" (qtd. in Williams 1960: 176). Elaborating on this aspect of culture, Williams pinpoints that, "The first emphasis of culture was an emphasis of the function of certain kinds of thought and feeling in the whole life of man: a function properly described as moral" (joyce180). Having all the ideas, mentioned above, concerning culture, Williams (1960) finally wraps up the discussion by mentioning that, "What we sometimes call 'culture'-a religion, a moral code, a system of law, a body of work in the arts- is to be seen as only a part, the conscious part of that 'culture' which is the whole way of life" (254).

Williams believes that 'culture' and 'civilization' were previously 'interchangeable terms;' but, then, civilization came to be seen as something "superficial "and "a cultivation of 'external' properties-politeness and luxury" which were against "'human' needs and impulses;" that's why civilization was the point of attack that led to "alternative sense of 'culture' -as a process of 'inner' or 'spiritual'... [which] associate [s] culture with religion, art, the family, and personal life as distinct from or actually opposed to 'civilization' or 'society' in its new abstract and general sense" (14). From such perspective, then, culture came to be seen "... as a general classification of 'theatre', religion, and the institutions and practices of meanings and values" (14-15).

\subsection{The Role of Religion in "The Boarding House"}

In the next story 'the boarding house', Joyce creates a cultural and non-secular conflict. The idea of divorce is highlighted once Mrs. Mooney divorces and separates along with her husband. After Mr. Doran had fallen with Polly, Mrs. Mooney's daughter, it's discovered and therefore the priest is summoned. Doran was a committed member of the Catholic Church and had a strong belief in their doctrine system. He says that he had lived an upright life for many a part of his life except once he fell with Polly. He was delineated as quiet cool man who had respect for both himself and others. The priest instills of concern in Doran and even magnifies his case to appear sin. Being a strong believer within the catholic doctrine, Doran's conscience is greatly disturbed and he appears to spend a lot of his time thenceforth simply puzzling over his mistake. He's judged by what he believed in and this makes him feel guiltier of what he had done. Doran is forced by the circumstances to travel against his will and marry Polly. He had his own reasons of not marrying Polly however as a result of the priest had imputed concern in him, he had to adapt to what he had been told. He had been created to appear just like the prodigal son who had been given another chance to live. From this story, it's terribly clear that religion encompasses a vital influence over one's decisions since it creates anunknown.

At the same time, Joyce presents us with an image of Ireland where religion is the governing force in determining equitable situations. This is clearly apparent when Mrs. Mooney experiences trouble with her marriage and seeks a separation. This situation is described as, "She went to the priest and got a separation from him with care of the children" [14]. The fact that Mrs. Mooney went to the priest to solve a domestic dispute, and not to an attorney shows that the citizens of Ireland regarded the church as the head figure of Ireland. This is evident that when religion is the head of state, people are subjected to the moral and ethical beliefs.

The example in "The Boarding House" is fascinating one, showing that the priest present at Mr. Doran's confession made him feel so terrible about his situation that he felt as if all was lost [15]. Joyce's message here was to show the attitude of the Church toward its members, one is the domination and control.

In "The Dead" Joyce criticizes the Irish society as he was deeply disappointed in it, he exiled himself from Ireland. The Irish are seen as hypocrites, spiritually and morally paralyzed by the nets of social norms and conventions. Religion was an integral part of Ireland during the modernist period, tightly woven into the social fabric of its citizens. The Catholic Church was a longstanding tradition of Ireland.

\subsection{The Role of Religion in "The Dead"}

In "The Dead," there is more complex and intriguing way in which Joyce attacks and criticizes the Church. It is a short story filled with references to Catholic theology and is a symbolic yet direct criticism of the Church by Joyce, who points out its flaws through characterization of them in main characters and in particular uses of imagery. He shows that the Catholic Church, though portrayed by Gabriel as a great being, is in reality a corrupt, false institution, and can only be effective if it changes its ways to be more accepting of all people. He ultimately teaches the reader that if no action is taken, the Church and its corrupt followers will suffer the very punishment they preach: that of a symbolic eternity in hell because of $\sin$. In other words, he warns of its eventual failure as an institution, and even passes his own final verdict upon it. Gabriel, the main character, offers an interesting perception on Joyce's thoughts toward the Catholic Church, definitely how he characterizes the domineering approach of the Church in his interactions with others. Joyce paints Gabriel as a man who is proud, arrogant, and who enjoys attention and control.

At the beginning of the story, he is represented as a man who speaks sneeringly to or about others, especially women. For example, when speaking about his wife, he says scornfully, "my wife here takes three mortal hours to dress herself" (153). Speaking to Lily, he teases her in a way that 
makes her feel rough when he jokes about her "young man" that he hopes they will be seeing soon (154). Also, when speaking of Gabriel to her aunt Kate, Gretta herself says the line, "you'll never guess what he makes me wear..." (156). These are just three examples of a better list which serve to show that Gabriel seeks control and power over others. It shows that this is symbolic of the Catholic Church, and how Joyce saw it as a dominant entity in the lives of the Irish. He was no doubt influenced by some of the philosophical thinkers of his time, such as George Moore [16].

He had taught me to pronounce Latin properly. He had told me stories about the catacombs and about Napoleon Bonaparte, and he had explained to me the meaning of the different ceremonies of the Mass and of the different vestments worn by the priest. Sometimes he had amused himself by putting difficult questions to me, asking me what one should do in certain circumstances or whether such and such sins were mortal or venial or only imperfections. His questions showed me how complex and mysterious were certain institutions of the Church which I had always regarded as the simplest acts (3).

The priest wants the boy to be just like him. The boy learns so far about catechism and the world of religion.

The duties of the priest towards the Eucharist and towards the secrecy of the confessional seemed so grave to me that I wondered how anybody had ever found in himself the courage to undertake them; and I was not surprised when he told me that the fathers of the Church had written books as thick as the Post Office Directory and as closely printed as the law notices in the newspaper, elucidating all these intricate questions. Often when I thought of this I could make no answer or only a very foolish and halting one upon which he used to smile and nod his head twice or thrice.

But the priest influences the boy's way of thinking and faith and he encourages the boy to learn by heart as the religious man had made me learn by heart. Consequently, this little creature believes that has committed simony, causing the unnamed boy repeating everything the world paralysis. In addition to that, religion has consequences even on the priests themselves. For instance in the case of Father Flynn - the duties of the priesthood was too much for him. And then his life was, you might say, crossed." (6).

People were more liable to corrupt priests than to God Himself. This is a belief seen in "The Dead," as Gabriel can be simply seen as a characterization of the Catholic Church's mentality of lording over its members. Gabriel's personality which reflects Joyce's attitude toward the Catholic Church is his duplicity. It begins with his conversation with Miss Ivors, where he exposes his true thoughts concerning Ireland, saying that he plans to vacation in nations besides Ireland, that "Irish is not [his] language," and that he "is sick of [his] own country" (164-65). His behavior shows his definite feeling.

Gabriel `s hypocrisy is exposed during his dinner speech which happens mere moments later. This discourse is laced with false patriotism for Ireland, as well as an extremely sincere view of his nation. For instance, he says, "our country has no tradition which it does so much honour... as that of its hospitality" (176). He declares, "the tradition of... Irish hospitality, which our forefathers have handed down to us..." (176). It shows his artificial love of Ireland. Gabriel easily pretend in front of an audience how much he loves Ireland. Finally, the final quote in The Dead is really shocking line. Joyce's courage to continue writing, even after the first Dubliners print run was destroyed. How many Irish men would've had the courage to say in 1916, "No God for Ireland! He cried. We have had too much God in Ireland. Away with God." It took courage be honest about humanity when people wanted to ignore the truth.

Joyce conveys in another theme of religion the story 'Grace' a drunkard man is helped by his friends to change his evil life. They believed that the only way is to change friend's habit is by creating him believe a religion that would direct his mind to the positive. This means that religion influences ones character. As mentioned earlier, religion forever has the result of creating an unknown fear in people who believe in it and thence create them live in line with their doctrine. In this story conjointly, there is conflicts between Protestants and Catholics. Catholics believe that Protestants can't be money lenders because of what they believe and nobody convince them otherwise. They really hate Protestants simply because they have been made to believe in it. Statistics show that the height of Protestant popularity occurred between 1881 and 1911, the same time period Joyce was writing Dubliners.

Bowker stated that Joyce believed that the Church "hated 'human beings,' and he wanted to escape the atmosphere of religious tolerance" in his early years (93). For the Church to be prejudiced of others and to show such dislike and hatred toward other human beings would break one of the two great commandments as taught by Jesus Christ: "Thou shalt love thy neighbor as thyself" [17]. If the Church professed to follow Christ and His teachings, and if it believed that "on these two commandments hang all the law and the prophets" [17], then in Joyce's eyes it would most definitely be seen as immoral and sinning. Joyce believes that the Church was held down by the very sins it condemned, such as lust, lying, and hypocrisy.

\section{Conclusion}

In conclusion, this chapter intended to analyze concept of religion within Cultural Materialism framework and looked upon their influence and active interaction in building up of society and culture. Moreover, it intended to study how this factor is dominant in shaping the characters' life and status. In essence, all of these examples serve to convey a sense of dispassion and emptiness. Joyce wanted to make one final attack against the Church that he despised so much during this time of his life. By placing the abovementioned characterizations of the Church within a story so encompassed by emptiness, Joyce's final message to the Church is clear: It is a dead institution, devoid of truth and hypocrisy. Joyce wants it to be known to all people that he 
believes that there is no truth in the teachings of the Catholic Church, and that it will soon be exposed as a deception. Joyce proclaims in Dubliners anger at a culture he feels is paralyzed by Catholic dogma, British exploitation, its own proponents for self-delusion, alcoholism, and Irish hyperbole and blarney. Joyce introduces complex ideas concerning religion and spirituality, especially regarding his conflict with the Catholic Church. Because of the injustices he saw coming from an institution that claimed to follow God and His teachings, Joyce set out to make these fears known to the rest of mankind. In this piece, Joyce not only teaches what the Church must do to change, but he shows the dangers of what might happen if it fails to do so. He makes it very clear that if it does not change, the Church will collapse. He is obstinate that the Church was an extremely damaged institution, and fell victim multiple times to the lust, anger, hypocrisy, and intolerance that so easily beset the human race.

\section{References}

[1] Abrams, M. H. A Glossary of Literary Terms. New York: Harcourt Brace Pub, 1993.

[2] Barker Chris. (2004). Cultural Studies: Theory and Practice. London: Sage publication Inc.

[3] Barry, Peter. (1995). Beginning Theory, an Introduction to Literary and Cultural Theory. New York: St. Martin press.

[4] Bei, Xu. On Reproducing Literary Style of Dubliners in Chinese, a Thesis, Shanghai International Studies University, November, 2008.

[5] Brannigan, John. New Historicism and Cultural Materialism. New York: ST. Martin press, 1998.

[6] Bulson, Eric. The Cambridge Introduction to James Joyce. Cambridge: Cambridge Press, 2006.

[7] Bigspy, C. W. E. (1984). A Critical Introduction to Twentieth Century American Dramas. New York: Cambridge press.

[8] Claire, Kilroy. An Introduction to today's Irish Novelists. Dublin: Ireland Literature Exchange, 2010.

[9] Daronkolahee, Esmaeel Najar. James Joyce's Usage of Diction in Representation of Irish Society in Dubliners: the Analysis of "The Sisters" and "The Dead" in Historical Context, The Journal of International Social Research Volume: 5 Issue: 23, Fall 2012. PP. 169-174.

[10] DeVault, Christopher M., Love and Socialism in Joyce's 'A Painful Case." A Buberian Reading, TCD library electronicdatabase, 2013.

[11] Dollimore, J. and Sinfield, A. Political Shakespeare: Essays in Cultural Materialism.

[12] Fargnoli, Nicholas A. and Gillespie, Michael P., Critical Companion to James Joyce: A Literary Reference to His Life and Work, Infobase Publishing, New York 2006.

[13] Freese, Lee and Burke, Peter J. Persons, Identities, and Social Interaction, Department of Sociology, Washington State University. Advances in Group Processes, Vol. 11. Greenwich, Conn.: JAI Press.
[14] Greenblatt, Stephen. Culture in Critical Terms for Literary Studies. London: Faber and Faber, 2012

[15] Harris, Marvin. Cultural Materialism: the Struggle for a Science of Culture, Walnut Creek, California: Alta Mira Press, 2001.

(https://www.google.com/search?q=Harris,+Marvin.+Cultural +Materialism).

[16] Hamlin, Madeleine. Geographies of Mobility in James Joyce's Dubliners, Literary Geographies, Vol. 2, No. 2, Syracuse University, 2016. PP. 128-143.

[17] Harris, Marvin. The Rise of Anthropological Theory: A History of Theories of Culture, Walnut Creek, California: Alta Mira Press, 2001.

[18] Howard, J. The new historicism in renaissance studies, in new historicism and renaissance drama, eds. Richard Dutton and Richard Wilson. London: Longman, 1992.

[19] Joyce, James. Dubliners: Authoritative Text, Contexts, Criticism. Ed. Margot Norris. New York: W. W. Norton, 2006.

[20] J. Giles and T. Middleton. Studying Culture: A Practical Introduction. The USA: Wiley, 2008.

[21] Kearney, Martin F., Robert Emmet's Rising of 1803 and the Bold Mrs. Kearney: James Joyce's 'A Mother' as Historical. London. 1981.

[22] Kiberd, Declan. Inventing Ireland. London: Random House, 1995. Print.

[23] Inglis, Tom. Local. Belonging, Identities and Sense of Place in Contemporary Ireland, in the Discussion Series: Politics and Identity No. 4, Institute for British-Irish Studies University, College Dublin, 2005.

[24] Kuznar, Lawrence A. and Sanderson, Stephen K. "Marvin Harris's Cultural Materialism and Its Legacy", Boulder, London: Paradigm Publishers, 2007.

[25] Lernout, Geert. (2009). "Religion." James Joyce in Context. Ed. John McCourt. Cambridge, U.K.: Cambridge.

[26] Lowe-Evans, Mary. (1989) Crimes Against Fecundity: Joyce and Population Control. New York: Syracuse University Press.

[27] Lozowski, Przemyslaw and Jarosz, Izabela. In Search of Cultural and Personal Experience behind woman in James Joyce's Dubliner, Artes Humanae, Vol. 1, 2016. PP. 157-174.

[28] Lodge, David, ed. (2000). Modern Criticism and Theory. New York: Longman Pub.

[29] Milner, Andrew. Re-imagining Cultural Studies: The Promise of Cultural Materialism, London: SAGE Publications Ltd, 2002.

[30] Moore, Jerry D. Marvin Harris. Cultural Materialism, Visions of Culture: An Introduction to [30] Anthropological Theories and Theorists (2nd ed.), Walnut Creek, CA: AltaMira Press, 2004. pp. 203-215.

[31] M. J. Smith. Culture: Reinventing the Social Sciences. Philadelphia: Open University Press, 2000.

[32] Nazarieh, Mehrdad. James Joyce Dubliners: How Religion Influences Conscience, The Clarion: International Multidisciplinary Journal, Volume 5, 2016. PP 102-106. 
[33] Newton, K. M. Twentieth Century Literary Theory. New York, 1995.

[34] Norris, M. Suspicious Reading of Joyce's Dubliners. Philadelphia: University of Pensylvania Press, 2003

[35] Pereira, Vijay and Malik, Ashish. The Identities of Emerging and Developed Multinational Corporations and their effect on business and society, Journal of Race, Culture and Identity. Australia.

[36] Prendergast, Christopher. Cultural Materialism: On Raymond Williams, Volume 9. London, Minneapolis: University of Minnesota Press, 1995.
[37] Roughley, Alan. James Joyce And Critical Theory: An Introduction. Ann Arbor: University of Michigan, 1991.

[38] Selden, Roman. Contemporary Literary Theory. London: Harvester Wheatheaf, 1993.

[39] Williams, R. Marxism and literature. New York: Oxford University Press, 1977.

[40] Wilson, R. and Dutton, R. ed (1992). New Historicism and Renaissance Drama. New York: Longman press. 